\title{
Innovation and Co-Creation Process within a Service Context: A Matter of Choice or Necessity?
}

\author{
John McManus ${ }^{1 * \#, ~ B a r r y ~ A r d l e y ~}{ }^{2}$ \\ ${ }^{1}$ Suffolk Business School, Suffolk, UK \\ ${ }^{2}$ Lincoln International Business School, Lincoln, UK \\ Email: *professormcmanus@gmail.com
}

How to cite this paper: McManus, J. and Ardley, B. (2019) Innovation and Co-Creation Process within a Service Context: A Matter of Choice or Necessity? Open Journal of Business and Management, 7, 25-42.

https://doi.org/10.4236/ojbm.2019.71002

Received: September 20, 2018

Accepted: November 19, 2018

Published: November 22, 2018

Copyright $\odot 2019$ by authors and Scientific Research Publishing Inc. This work is licensed under the Creative Commons Attribution International License (CC BY 4.0).

http://creativecommons.org/licenses/by/4.0/

\section{(c) (i) Open Access}

\begin{abstract}
The notion of service ought to be embedded in the psyche of those responsible for the design and delivery of service provision. Within an ever changing landscape, meeting customer expectations is a major priority for firms engaged in service provision. Enhancing the service experience lies in the context of innovation and entrepreneurship. The focus of innovation within business should take into consideration the unexpected, the nature of incongruities, process need and changes to structure. Innovation within service industries is widely recognised among researchers and practitioners as a key to gaining and sustaining competitive advantage. Increasingly, firms within service industries are placing new knowledge at the core of their strategies, especially knowledge about co-creation processes, knowledge of innovation and service design. In this context, the purpose of this paper is to explore the linkages between service development and co-creation processes to better understand the complexity of service innovation. The paper will first outline the notion of service and the context of service innovation. It will present a summarised view for management of service innovation. The paper will then move to illustrating how the creation and use of co-creation processes can be used to provide a shared understanding of what constitutes best practice.
\end{abstract}

\section{Keywords}

Service Innovation, Service Design, Innovation Diffusion, Co-Creation Processes

\section{Introduction}

This paper presents both a theoretical outlook of the challenges faced by service

${ }^{\#}$ At the time of writing this paper Dr. McManus was working at Suffolk University. 
organisations in particular those sectors which rely on innovation as a source of new knowledge and technological advantage. The significance and practical value of this paper is to provide a research narrative which defines the linkages between service development and co-creation processes to derive a better understanding of the complexity of service innovation and its application and implications for managers and academics in the future development and implementation of co-creation.

Some researchers believe in "integrated innovation" that is an approach which incorporates advances in technology, marketing, and behavioural sciences. A number of academic papers and books emphasize on the multifunctional nature of services and service process [1] [2] [3] [4]. The work by Botten and McManus [5], and Howitt and McManus [6], highlights the complexity and competitive nature of services in different service sectors. Other authors [7] highlight complexity in services based on differential dimensions which incorporates service practice and performance. Whilst other authors [8] [9] [10] [11] highlight the importance of innovation as a means to increasing performance and productivity. However, innovation in the service sector is not fully represented in the literature. The predominance of traditional manufacturing and technological innovation has been partially responsible for the lack of published papers which argue the case of services sector innovation. Despite this recognition and interest in the topic, how innovation occurs and how it affects growth is poorly understood. Furthermore, much of the literature on innovation concentrates on market-based innovation [12], leaving service innovation relatively unexplored.

Various studies have discussed the research priorities in the realm of service. Furrer and Sollberg [13] argue that internationalization, technology transfer, and innovation are new emerging service topics. Djellal and Gallouj [14] suggest a number of research areas for providing a deeper understanding of the link between service innovation and growth. One of these areas concerns innovation in services and its impact on growth and employment. Innovation in services should indeed be a high priority for service researchers. Researchers have devised the service imperative to promote service research [8] [9]. Key issues include new and innovative services, and service culture, and technology enabled services. In this context, service research efforts need to focus on providing an understanding of the benefits and limitations of service innovation and co-creation processes. Research into different aspects of service innovation and co-creation processes could provide new ideas for practitioners interested in learning about new markets, strategies, and entrepreneurial initiatives. Academics and practicing managers should learn to facilitate broad innovation activities in the market and to build service systems supporting innovative business ideas and activities.

\section{Research Methodology}

This paper is based on a review of the existing literature available in academic libraries, and institutional databases which contain material on service management and service innovation, by which service innovation and co-creation could 
be examined to provide insight into the broader concepts of what constitutes innovation in service and what constitutes shared value within the process of co-creation. In this context contextualized papers and their findings were derived from three sources ABI Inform (Proquest), Business Source Primer (EBSCO) and Scopus. These databases contain many of the top academic journals (see Table 1).

Literature on the relationship between innovation and co-creation process is explored from the resource perspective to inform our understanding of the service innovation process, through a review, involving works exploring the DART model as well as titles pertaining to more general co-creation topics. In terms of contribution to knowledge the objective is therefore to provide further understanding of service innovation and the co-creation process. Some new components and processes are explored in order to make the framework more comprehensive. The scale employed in the research was developed through a four-stage question process. Namely:

1) Describes the notion of service and the context of service innovation, by examining both explicit and implicit expectations.

2) Examine how management of these expectations increases the likelihood of achieving customer satisfaction.

3) Examine the context of service innovation and recommend a means which combines the different types of approaches for managing the innovation process.

4) Explain how co-creation processes and best practice is contributing to the concept of service innovation and management, discussing the implications for further research.

Throughout the review, the field of service innovation emerges as a reasonable contributor to service research on co-creation. This paper concludes with providing productive grounds for future research, such as: Which parts of the service innovation process are most fertile for co-creation? Which outcomes influence and lead to enhanced performance of co-creation innovation and why?

The paper is organised as follows the outline and notion of service and the context of service innovation is discussed. The paper will present a summarised view of ideas and theories for the management of service innovation. The discussion will then move to illustrating how the creation and use of co-creation processes can help provide a shared understanding of what constitutes best practice in this emerging field of study.

Table 1. Journal search results (JEL classifications M11, 031 \& 033).

\begin{tabular}{ccc}
\hline Database & $\begin{array}{c}\text { Number } \\
\text { Journals } \\
\text { Reviewed }\end{array}$ & $\begin{array}{c}\text { Papers } \\
1990-2017 \\
\text { (see references) }\end{array}$ \\
\hline ABI Inform & 8 & $20(19 \%)$ \\
Business Source Primer & 11 & $36(35 \%)$ \\
Scopus & 14 & $48(46 \%)$ \\
Totals & 33 & $104(100 \%)$ \\
\hline
\end{tabular}




\section{The Notion of Service and Service Innovation}

Commenting retrospectively there is only one valid definition of business purpose which is to create a customer [15]. This statement is true today as it was sixty years ago and applies to both product and service industries. Service industries are made up of firms that primarily earn revenue through providing intangible products and consumer services, and encompass businesses such as hotels and banks to business services such as IT and legal and large-scale public sector services such as health and education [5]. The notion of what constitutes a service is documented in the literature [5] [16] [17] [18]. Services are often seen as intangible processes and dynamic interactions comprising of moments of truth [19], which are deeply ingrained in the customer's psyche where implicit promise awakens an explicit expectation. The point to emphasise here is intangibility which implies that a service is experienced; it is rendered; physical ownership cannot occur. Therefore, the conceptual boundaries or linkages of innovation and marketing must be expanded to accommodate the property of service.

The work by [20], distinguishes explicit and implicit elements of relationship within product or service offering. Liljander and Strandvik's views on service quality as a cognitive evaluation of service compared to some explicit or implicit comparison of behavioural benchmarks [20]. In this context, the service provider must always satisfy implicit expectations and understand the indistinct expectations so that they can be made to emerge as explicit expectations which empower service users [6]. Our knowledge of the association between anticipated and experienced service encounters is to some degree limited by the way the service is created and offered to the customer. The conceptual model of service is often characterised as a static entity. Grönross, [21], highlighted the need to construct dynamic service models to be able to come to a real understanding of what is meant by service. The work of Gummesson [22], highlights the importance of collaboration in which the service provider sets out to create value for the customer by collaborating with the customer himself. Furthermore, the crucial role of the customer in service innovation and service production makes it necessary to recognize that customers are also part of the service function [23]. This is also emphasised by Drucker [24], who highlights that partnerships with responsible customers and service providers is the way forward for most organisations looking to add value.

The initial test of what customers' value and whether value can be delivered requires imagination and empathy for the emotions that actually drive people's behaviour. Again, adding value is often reported as collaboration within service provision. Value in service-based organizations is created through the integration of intangible resources and capabilities such as knowledge, competences, cognitive-centric workforce, and customer collaboration [25].

Services are often the product of diversification and value chains, where in some aspects the diversity of the different sectors can make it difficult to make useful generalisations concerning the means by which value is added within 
service organizations [5]. Therefore, a considerable amount of research has been focused on developing service classification schemes. The work by Judd classified services according to three categories: rented goods, owned goods and non-goods services [26]. Similarly, Rathmell categorized services according to type of buyer, buyer motives, buying practices, type of seller, and degree of regulation [27]. Even though these classifications show how some services are different from the others, they do not provide much useful insight into the innovation, design and management of service processes from an operational perspective. Research that is more topical is related to managerial practices and performance which identifies some useful findings into service design and innovation practices [6] [28]. The underlying logic of these authors research is that the adoption of best practice has a direct link to the attainment of high service performance which, in turn, leads to superior business performance and competitiveness [29]. Innovation is recognized as one of the five key drivers of firm-level productivity along with investment, skills, enterprise, and competition [30].

\section{Context of Service Innovation}

Service innovation has become a term referring to innovation taking place in the various contexts of services, including the introduction of new services or incremental improvements of existing services. There are as many definitions of "innovation" as there are experts. The term covers a broad spectrum of business activity and can be applied to new or improved products (as at Microsoft and Nintendo), processes (as at Toyota, Walmart, Procter \& Gamble), experience (as at Disney, or Google), or business models (as at Hewlett Packard, Reliance, or Goldman Sachs).

Various attempts have been made to define innovation. For example, the economist Joseph Schumpeter suggests Innovation is "the commercial or industrial application of something new-a new product, process or method of production; a new market or sources of supply; a new form of commercial business or financial organization." (OECD-Eurostat, 2005: p. 46). A more comprehensive definition of service innovation was proposed by Ark, p. 16 [31]:

" $A$ new or considerably changed service concept, client interaction channel, service delivery system or technological concept that individually, but most likely in combination, leads to one or more (re) new(ed) service functions that are new to the firm and do change the service or good offered on the market and do require structurally new technological, human or organizational capabilities of the service organization."

A distinctive aspect of service is the way the service is designed and promoted within the organisation. Service design is highly dependent on innovation which is dependent on the way creativity is nurtured within the organisation. Innovation is not like most other business functions and activities. There are no reliable process inputs, templates, rules, or even measures of success, in a sense; each act 
of innovation is a unique achievement underpinned by process. Inputs to the innovation process are considered assets (e.g. capital) because they are used repeatedly in a single innovation channel or are used in a pipeline resulting in a different product. Innovation is driven by a firm's investment in tangible capital (such as infrastructure) or intangible capital (such as organizational structure, human capital). These innovative activities could lead to tangible outputs (e.g., new or improved products or processes) and intangible ones (e.g., more experienced employers likely to engage in future innovations), as suggested in Caruso [32].

Peter Drucker suggests that innovation is also about entrepreneurial and creative functions in business [33]. If the purpose of business is creating a customer, the purpose of innovation is to some extent about keeping them. The economist Joseph Schumpeter points out the discovery and realization of creative responses are the characteristic functions of the entrepreneur: "the doing of new things or the doing of things already being done in a new and innovation way" ([34], p. 223).

Schumpeter's [35], idea that more innovative firms will tend to grow bigger and more profitable, with profitability being due to superior innovative capability tends to support Hayek's theory on competition [36]. For example, when there is uncertainty about the best production methods and organisational forms then price-cutting, price discrimination, marketing campaigns and other strategic activities that create advantages for some organisations over others are the competitive means by which innovations are gradually discovered and diffused.

Service industries are challenged on many dimensions trying to service customers better in order to sustain their custom requires commitment and engagement from the organisation and its staff. In short, management should provide and demonstrate abilities in planning, and leadership skills, in which relevant experience and talent often complement each other. Service organisations must learn to think of themselves not so much as service entities, but as creative and learning organisations which exist to serve their customers. If the focus is directed towards creative and innovative behaviour, then positive responses or actions tend to follow. Schumpeter, for example, differentiates between two kinds of behavioural reactions: the "adaptive response" and the "creative response" ([34], p. 222). While the adaptive response follows the well-known paths within existing practice, the creative response opens up fundamentally new ways of economic and social development and alternative ways of assessing value.

Drucker [33] defines innovation as the act that endows resources with a new capacity to create wealth (and value). The term value as many different meanings Lepak et al., for example, suggest that value creation depends on the relative amount of value that is subjectively realised by a target user (or buyer) who is the focus of value creation [37]. However, within services the process of value creation and the mechanisms that allow the creator of value to capture value is dependent on many variables such as the type of industry, markets, revenue, 
number employees, investment in R \& D etc. However, in the context of service innovation, value creation may be viewed as a persuasive avenue for organizations to create competitive advantage.

In the literature on strategy, competitive advantage is often linked to the process of innovation and the opportunity to exploit a given market. The achievement of competitive advantage through services is largely derived from the firm's ability to create internal alignment among critical organizational elements in order to fit market needs [38]. The function of the service strategy for any service provider is to market consider opportunities, decide the service offering, build the service value chain and to design the service. The stronger each of these elements is the better and more robust the service will be. Innovation plays a significant part in exploiting service opportunity [5], for example, firms which are more innovative can capture higher profits than their competitors within a given market or service sector. The size of a potential opportunity produced by a particular market is clearly an important consideration, as is the likelihood of a sustained overall all growth of market revenue. Service providers often seek out those markets which offer the greatest opportunity, knowing that if they can become established in such markets, significant revenues will follow. Like products, successful services pass through a development phase. During this phase, value creation becomes critical only to the extent it is necessary for a firm to sustain its return on customer investment.

The last decade has been characterized by far-reaching, or even radical, change in value creation practices, largely driven by developments in communications and information technologies (IT) together with the emergence of the digital economy which has become for many service providers a central source of economic productivity and collective influence. As a result of these developments, we have seen a proliferation of service diversity, especially in the areas of retail banking, mobile communications and applications development. As a result of this diversity, innovation in services has involved transformation in a variety of aspects ranging from how the service is designed and developed to how it is delivered and managed [6].

Historically, the service sector has been slow to adopt IT and other technology as compared to manufacturing. This may be attributed to the greater heterogeneity and dynamism in services as a result of which service innovation cannot be organized as a standardized R \& D model as in manufacturing [39]. The heterogeneity in services means that innovative activities need to be tailored to different service contexts calling for a more dynamic approach to organizing innovation in services as compared to manufacturing. Homogeneity in services can create difficulties during the process of service development (and may cause concern when measuring quality, output, and value).

The market segment indicates the type of customer for whom the services and the value proposition is designed. Arguably, some of the biggest opportunities for the cultivation of innovation and service design, and therefore for the practice of service differentiation, exist in new market segments such as digital markets 
which include social media, on-line media and applications, multimedia, and mobile services. Products and services in these sectors have proven to be adaptable and can be redesigned and less expensively customised to individual requirements. Think how on-line services have progressed in the last five years where retail insurance and banking products can be tailored to individual requirements within 24 hours (and in some cases within minutes of a transaction taking place).

\section{Management of Service Innovation}

It is important to note here the words management and innovation. We can highlight some of the issues in this section by looking at the meaning of these words in the context of service management. Management researchers often discuss the need for an integrated approach to innovation management. Successful innovation practice is based on organized and efficient management [3] [5] [33]. During his life-time Peter Drucker long argued about the importance of management, and the challenges management faces both day-to-day and in the longer term. Drucker a social scientist was among the first of his peers to see the limits of large organizations and their authoritarian hierarchies. He also foresaw the emergence of the service economy and the arrival of knowledge workers motivated by the challenges of a post industrial society. Harnessing their talents, he argued, required a new approach to management.

In defining this management approach Drucker [33] took the ideas set forth by Schumpeter [35] a step further. Schumpeter's type of innovation could be systematically undertaken by managers to revitalize any type of business organization. By combining managerial practices with the acts of innovation, Drucker argued, business can create a method of free enterprise that would result in the institutionalization of entrepreneurial values and practice, which can be strategically employed by any organization at any point in their life, whether they are a business start-up or a firm with a long corporate history.

In many service organizations, the great majority of people work with others who have different skills, tasks and responsibilities. In essence, management is about understanding "what people do and how they do what they do". Management is about taking responsibility for these interrelationships and as such a necessity to growth. Those organizations which form part of the service and knowledge economy are no longer built on force but on trust, and this is a crucial aspect to their survival and competitive position in the market place. In this context, the challenges within management for many may seem self-evident. However, management requires new and unprecedented things from the individual manager, and especially from the individual knowledge worker. In essence providing a working environment in which each individual thinks and behaves like a manager.

In a global economy in which success has become so important, having options becomes increasingly vital. At the strategic level, management is concerned 
with investment options. Investment options involve the future and in part, management is about shaping the future [40]. Shaping the future is about creating both products and services that focuses on high quality, personalised user experiences, creating a service culture that focuses on service excellence. Excellence in services is delivered through an interaction between service design and service outcomes. Service satisfaction is generally the difference between the perceived service and the expected service and is determined at the time of the service encounter [41] [42].

There is scope to innovate across a variety of service interactions ranging from those that involve the exchange of intangibles like information as in education services, to tangible elements as in transportation services [5]. Sampson and Froehle argue that customer inputs into the creation of services, makes service innovation complex and multidimensional in nature [43]. The extent of customer interface in the service innovation process results in a high degree of customization in services that in turn increase their heterogeneity. The intangible nature of services, relative to products, makes these open and collaborative customer and provider exchanges even more challenging to manage. In this context, it is only common sense to involve customers, and in particular key users, in the innovation process. It is also important to engage other key stakeholders across all stages of service innovation rather than just at the end of the process.

Input to service innovation and excellence suggests how organisations could view service innovation to satisfy and engage the customer. The services industry is now so complex that this requires strong and well-designed processes as well as managers who can engage with employees and customers with the right skills and competencies. This is a combination of hard and soft approaches towards service innovation and management. Innovation in services is mainly reliant on uniqueness created through intangible resources and processes such as knowledge, abilities, talent, attitude and the propensity towards continued learning. These attributes are sometimes akin to human capital which is the overall value of intangible assets that employees bring to the organization.

Innovation activities draw upon a variety of inputs. Inputs can be both tangible and intangible. Tangible inputs have a physical embodiment and cost. Intangible inputs do not have a physical embodiment are commonly referred to as knowledge assets [44]. Approaches for evaluating and measuring business related activities in services, incorporate both financial and non-finance related measures of assessment. In the context of "service drivers", these assessments include elements of quantitative and qualitative performance (time, cost and quality). Often managers perceive business performance as complex a phenomenon which is sometimes difficult to quantify [45].

Empirical research and surveys suggests that drivers of service management (or forms of interactions between customers and the organisation) are relevant to the initial success of new services [5] [45]. For many firms there is a key imperative to success that is "time to market", which is driven by market conditions 
whether local, regional or global. There is however, a substantial difference in scale and investment needed to launch a service in each of the markets. The area of reference for many services is the local or regional market, despite tendencies of internationalisation that become increasingly relevant for others. The crucial factor of innovation decisions is still the intensity of competition in the market for a new service [46]. In measuring success in the market, we often refer to market share, return-on-investment or net profit. As regards the measurement of service innovation, a "one-size-fits-all" approach will not be appropriate to innovation in services, as services embrace a wide variety of providers, which will differ according to the degree of knowledge that they require to operate. In considering which measurements to use there is a need to consider alternative metrics; traditional metrics for product innovation such as percentage of sales from new products cannot always be directly transferred to service innovation [47]. In the development of service, metrics both financial and non-finical measures should comply with realistic expectations of both the organisation (provider) and the customer [48].

\section{Co-Creation Processes}

In the current networked world, service innovation is highly interactive and systematic in nature, since both public and private service organisations are embedded in wide value networks that include suppliers, intermediaries, customers and partners, and that combine their capabilities in co-creation processes [49]. In this context, the notion of consumer participation has a rich history in the literature on innovation, where customers are involved in the value creation process. For example, there is the case of the expert lead user customer [50]. Lead users closely advise the company on new product and service initiatives as they have a vested interest in the outcome. However, the very central role of customers in the value chain was first highlighted in a significant way by Vargo and Lusch [51]. They indicate that considerable business activity has shifted much of its dominant logic away from the exchange of product-centred tangible goods toward the exchange of intangibles, being specialised skills and knowledge. These can be brought to bear on products of all types, including services. The firm needs to recognise the fact that customers possess these intangible skills and are there to be used in the innovation process [52]. It means more than simply being consumer oriented though. It involves collaborating with and learning from customers and being adaptive to their individual and dynamic needs. This service-centred dominant logic implies that value is defined by and co-created with the consumer rather than embedded in physical offerings. The latter is represented by the notion of a goods dominant logic [51]. This traditional perspective sees the customer as a passive receiver of value, based on their role as payer and end user in the value chain. Here we examine the alternative possibility of changing the role of customers in services, such that they become part of co-creation process, either as individuals or as part of a firm organised commu- 
nity [53].

In this perspective, the skills knowledge and interactions of customers with the firm, facilitates and creates innovation. The consumer of today recognizes that they are a customizer and a producer of value [54] [55]. There are numerous examples of this, from the NIKE ID customisation process through to the LEGO customer communities that enable new products to be developed and on to current and future VR experiences that can only be created by the consumer in an experiential way [56]. In this context, Vargo and Lusch [57] distinguish between operand and operant resources. The former involves the use of physical resources which come together to produce tangible products, for example, this might be the level of technology in use in the firm, in the production process. In this context, resources are the skills and knowledge brought to bear on outputs. This distinction is very important, in that the notion and prominence of operand resources suggests that the service entity needs to adopt a strategic perspective, where the service entity as a supplier of skills and competencies, enjoys a closer and more positive relationship with the wider organisation, representing an essential element to innovation. This calls for collaboration between the organization and the service development entity. Because many services are increasingly information based the technology being used must support processes, systems and applications used for service provision and vice versa [58].

The traditional, goods-centred view regards producers and consumer as separate entities, whereas Vargo and Lusch [57] theorise service-centred view of marketing as having a heavy focus on continuous processes, involving the consumer in co-creation work. In addition, they recognise the role of other network partners in the co-creation project, a form of cross boundary collaboration that can also lead to innovation. These sorts of dynamics apply equally to a service setting, where consumers can become involved in creating the service experience. One way to look at this is to suggest that the key is not to create value for customers, but to mobilize customers to create their own value from the company's various offerings. Consequently, a key strategic task is the reconfiguration of roles and relationships among the constellation of actors in the network, in order to mobilize the creation of value in new forms. In health markets, for example, consumers could be co-opted to suggest improvements in the physical servicescape and suppliers could be involved in co-creation processes that lead to new types of treatment, potentially through collaborative based software systems [59] [60].

Co-creation can offer clear advantages to companies, compared to conventional systems of meeting market demands. In business, the value creation system has been traditionally hierarchical, including lean systems. Manufacturers, who produce goods, will have them distributed by various intermediaries, such as distributors, wholesalers, and retailers. In other situations, service providers largely construct the offering. In all cases, the firm keeps the customer at a distance and updates its systems of intelligence with customer preferences by fre- 
quent contact through market research. The firm will then be able to react to the new preferences of customers. By using tools such as segmentation, the traditional business produces resources for action, by reducing the differences between customers, subsequently providing offerings to the segments which contain convergent customers [52]. Alternatively, customers with a co-creation role can potentially create systems which enable co production to occur, based on differences. Consequently, the focus of the company moves to one where it helps create motivations and mechanisms for self-organised activities, incorporating rich and varied interactions, where high quality, co-created innovative output is produced. Arguably, customers are no longer satisfied with a "one size fits all" product and instead, demand increased levels of variety and personalisation, an aim that co-creation can help to fulfil [61].

\section{What Constitutes Best Practice}

In terms of empirical evidence the issues of co-creation and the DART framework (Table 2) are an underdeveloped area. The only facet of co-creation that is currently supported by a substantive body of research is the involvement of customers in innovation [62]. The co-creation viewpoint highlights the importance of interactions between the firm and its customers, which are related to the DART model [63]. Arguing for co-opting customer involvement in the value creation process, they emphasise the importance of understanding and implementing the processes of co-creation through its key building blocks of dialogue, access, risk assessment, and transparency. Prahalad and Ramaswamy suggest companies can create new and important capabilities by combining these

Table 2. DART logic and relevance.

\begin{tabular}{|c|c|c|}
\hline & Process overview & Value within co-creation \\
\hline $\mathrm{D}$ & $\begin{array}{l}\text { Dialogue: tools and policies to promote } \\
\text { customer, market, sales and profitability. }\end{array}$ & $\begin{array}{l}\text { The aim is to provide customers sufficient } \\
\text { opportunities to share with organisations } \\
\text { their ideas for increasing satisfaction within } \\
\text { the product and service experience. }\end{array}$ \\
\hline A & $\begin{array}{l}\text { Access: physical infrastructure and processes } \\
\text { to support customers and information access. }\end{array}$ & $\begin{array}{l}\text { The aim is to provide customers with the } \\
\text { freedom to choose their preferred delivery } \\
\text { method for product and service. Giving } \\
\text { customers the autonomy to choose their } \\
\text { preferred time of receiving products or } \\
\text { services. }\end{array}$ \\
\hline $\mathbf{R}$ & $\begin{array}{l}\text { Risk assessment: tools and processes to } \\
\text { support business processes to assess customer } \\
\text { viability of customer engagement. }\end{array}$ & $\begin{array}{l}\text { The aim is to provide customers with relevant } \\
\text { information about products and services, so } \\
\text { they can assess the benefits of such products } \\
\text { and services on their own merit. }\end{array}$ \\
\hline $\mathrm{T}$ & $\begin{array}{l}\text { Transparency: freedom of information to } \\
\text { promote logical and physical design of } \\
\text { business processes to reduce risk. }\end{array}$ & $\begin{array}{l}\text { The aim is to make available to customers all } \\
\text { relevant information in order to smooth the } \\
\text { advancement and use of products and } \\
\text { services in order to inspire customers with } \\
\text { new ideas for consumption and application. }\end{array}$ \\
\hline
\end{tabular}


four DART building blocks in different ways. Service sector firms could usefully adopt this model in their own strategic explorations of co-creation activity (Table 2). Another way to approach co-creation activity is through the use of the internet. Initially, the internet fostered a one-way communication stream from firm to consumer. Like all communication networks, the internet is about establishing and reinforcing connections between people, which in turn leads to effective co-creation activity [64].

In relation to Table 2, Berthon [65] makes the point that web technologies such as web 2.0; have caused a shift in locus of activity from the desktop to the web, and a shift in locus of value production from the firm to the consumer, and finally, a shift in the locus of power away from the firm to the consumer. In web 2.0, new forms of communication, such as discussion forums have appeared, facilitating an environment which has great potential for interactivity and interpersonal use, leading in turn to value generating activity. Over time, this multi way communication process has enabled the internet to emerge as a truly global means of connecting individuals and organisations for the purpose of co-creating products and services. As evidenced by research, product development can be strongly influenced by interactions with online communities, ones that are focused on the same product or service type [66]. A physical offline community may have a large population within a particular geographical boundary, with a few people interested in the same subject. However, online communities allow people-who share an interest in a product, industry, market or brand-to interact and produce value without the constraint of the prior, traditional and limiting boundary. In line with this, numerous examples exist of co-creation taking place not only in physical products, but also through service based online communities [67]. This collective process puts the lay user, rather than the firm, centre stage in terms of design, collaboration, co-creation initiatives and community activity.

\section{Conclusions and Implications for Future Research}

Co-creation raises some overarching strategic questions for the service organisation that need addressing [58] [68]. For instance, at management level, is the company, directed towards developing a specific solution to a problem or attempting to develop a specific product? In the first case, this might be customer generated ideas on how to reduce queues, and in the second, a product that replaces a queue, that might be for example, a mobile phone app generated through co-creation activity. Additionally, co-creation could be linked to the strategic process of opportunity identification where the intention is to produce ideas that can open up the possibility of a new product initiative [55]. Here, the resulting objective can be related to continuous improvement in service products, or to the creation of radically new service products. In summary, co-creation forces the firm to affirm in a proactive way, an intensive involvement with its customers in the innovation process. The central feature of co-creation is that 
customers can be a leveraged as compliant and interested resources, as representative of the best in human capital and as knowledge based asset and competency for the firm. The logic inherent in co-creation is a compelling one for the service provider, as it is centred on the importance of co-created customer experiences in delivering value. In this sense, co-creation and the service dominant logic perspective can be seen as being very much an entrepreneurial, forward thinking initiative, worthy of take up by the service organisation, for all the outstanding potential that it involves.

By taking a conceptual view of the linkages between services, service innovation and co-creation processes this paper contributes to both service management and innovation theory by highlighting the complexity of innovation in the context service integration. It is evident that different features become important, depending both on current service offerings, systems, and processes and on structure, and market characteristics. Empirical research suggests that drivers of innovation and service management are relevant to the initial success of new services [5] [25] [45]. To date, most studies in this research stream have focused independently on innovation, service orientation or service design, but few empirical studies have investigated the linkages between innovation, service orientation, and co-creation processes. The use of a holistic approach to guide research to investigating the effect of service innovation, and best practice to inform future service development is paramount to competitive success. In order to have a competitive service offering, the firm must think in terms of wholes and in terms of integration of structure and processes. Neu and Brown suggest the need for increased integration between service functions is supported by the need to engineer co-creation value chains rather than autonomous structural forms which do not support the intent to satisfy highly complex customer needs [69].

The main contribution of this paper is that it has taken a stride to enhance the link between service innovation and co-creation processes. However, further research is required to build on the thought processes and material in this paper. Specifically in the area of service innovation and the wider field of co-creation processes which impact both customer value and performance. The limitations of this study derive mainly from the available literature on service innovation, research priorities and source material such as published papers. Future research should be conducted to examine the shifting focus of service orientation and how the creation and use of co-creation processes can be used to provide a shared understanding of what constitutes best practice in service innovation.

\section{Conflicts of Interest}

The authors declare no conflicts of interest regarding the publication of this paper.

\section{References}

[1] Cherry, C.K. (1994) Re-Engineering Harnessing Creativity and Innovation. Journal of Cost Management, Summer Edition, 49-61. 
[2] McManus, J. (1997) Re-Engineering Your Business. Pitman Publishing, UK.

[3] Chesbrough, H. (Ed.) (2003) Open Innovation: The New Imperative for Creating and Profiting from Technology. Harvard Business School Press, Cambridge, MA.

[4] McManus, J. (2004) A Stakeholder Perspective in Software Project Management, Journal Management Services, 48, 8-12.

[5] Botten, N. and McManus, J. (1999) Competitive Strategies for Service Organisations. Ichor Business Books, West Lafayette.

[6] Howitt, M. and McManus, J. (2014) Creating the Service Design Interface. Journal Management Services, 58, 38-44.

[7] Roth, A.V., Chase, R.B. and Voss, C. (1997) Service in the US. Severn Trent PLC., Birmingham.

[8] Miles, I. (1996) Innovation in Services: Services in Innovation. Manchester Statistical Society, Manchester.

[9] Miles, I. (1998) Services, Systems and Innovation: Cinderella Comes to the Ball. Services and Systems Workshop, CRIC, Manchester, 18-19 March 1998.

[10] Edvardsson, B. (1997) Quality in New Service Development: Key Concepts and a Frame of Reference. International Journal of Production Economics, 52, 31-46. https://doi.org/10.1016/S0925-5273(97)80765-7

[11] De Vries, E. (2006) Innovation in Services in Networks of Organizations and in the Distribution of Services. Research Policy, 35, 1037-1051.

https://doi.org/10.1016/j.respol.2006.05.006

[12] Bryan, K.A. and Lemus, J. (2017) The Direction of Innovation. Journal of Economic Theory, 172, 247-272. https://doi.org/10.1016/j.jet.2017.09.005

[13] Furrer, O. and Sollberger, P. (2007) The Dynamics and Evolution of the Service Marketing Literature: 1993-2003. Service Business, 1, 93-117. https://doi.org/10.1007/s11628-006-0006-7

[14] Djellal, F. and Gallouj, F. (2007) Innovation and Employment Effects in Services: A Review of the Literature and an Agenda for Research. The Service Industries Journal, 27, 193-214. https://doi.org/10.1080/02642060701206959

[15] Drucker, P. (1954) The Practice of Management. Harper and Row, London-Heinemann.

[16] Grönroos, C. (1990) Service Management and Marketing, Managing the Moments of Truth in Service Competition. Lexington Books, Lexington.

[17] Zeithaml, V.A., Parasuraman, A. and Berry, L.L. (1990) Delivering Quality Service: Balancing Customer Perceptions and Expectations. The Free Press, New York.

[18] Boulding, W., Kalra, A., Staelin, R. and Zeithaml, V.A. (1993) A Dynamic Process Model of Service Quality: From Expectations to Behavioural Intentions. Journal of Marketing Research, 30, 7-27. https://doi.org/10.2307/3172510

[19] Normann, R. (2001) Service Management: Strategy and Leadership in Service Business. 3rd Edition, Wiley, Hoboken.

[20] Liljander, V. and Strandvik, T. (1995) The Nature of Customer Relationships. In: Swartz, T.A., Bowen, D.E. and Brown, S.W., Eds., Advances in Services Marketing and Management, Vol. 4, JAI Press, London, 141-167.

[21] Grönroos, C. (1993) Toward a Third Phase in Service Quality Research: Challenges and Future Directions. In: Swartz, T.A., Bowen, D.E. and Brown, S.W., Eds., Advances in Services Marketing and Management, Vol. 2, JAI Press Inc., Greenwich, 49-64. 
[22] Gummesson, E. (1979) Models of Professional Service Marketing. Liber/Marketing Technique Center, Stockholm.

[23] Gallouj, F. and Weinstein, O. (1997) Innovation in Services. Research Policy, 26, 537-556.

[24] Drucker, P. (1992) Managing for the Future. Butterworth-Heinemann, Oxford.

[25] Agarwal, R. and Selen, W. (2011) Multi-Dimensional Nature of Service Innovation Operationalisation of the Elevated Service Offerings Construct in Collaborative Service Organisations. International Journal Production Management, 31, 1164-1192. https://doi.org/10.1108/01443571111178484

[26] Judd, R.C. (1964) The Case for Redefining Services. Journal of Marketing, 28, 58-69. https://doi.org/10.2307/1249228

[27] Rathmall, J.M. (1974) Marketing in the Service Sector. Winthrop, Cambridge.

[28] Voss, C., Chase, R.B. and Roth, A.V. (1999) International Service Study, Decision Line. 4-7.

[29] Armistead, C.G. (1990) Service Operations Strategy: Framework for Matching the Service Operations Task and the Service Delivery System. International Journal of Service Industry Management, 1, 6-17. https://doi.org/10.1108/EUM0000000002800

[30] Camus, D. (2007) The ONS Productivity Handbook: A Statistical Overview and Guide. Office of National Statistics, Hampshire.

[31] van Ark, B., Broersma, L. and den Hertog, P. (2003) Services Innovation, Performance and Policy: A Review, Synthesis Report in the Framework of the Project on Structural Information Provision on Innovation in Services SIID for the Ministry of Economic Affairs of the Netherlands. University of Groningen, Groningen.

[32] Caruso, D. (2008) The Real Value of Intangibles: Strategy and Business. Reprint No. 08302 .

[33] Drucker, P. (2015) Innovation and Entrepreneurship: Practice and Principles. Routledge Classics, New York.

[34] Schumpeter, J. (1947) The Creative Response in Economic History. Journal of Economic History, 7, 149-159. https://doi.org/10.1017/S0022050700054279

[35] Schumpeter, J. (1942) Capitalism, Socialism and Democracy. Unwin Hyman, London.

[36] Hayek, F. (1948) The Meaning of Competition, in Individualism and Economic Order. University of Chicago Press, Chicago.

[37] Lepak, D.P., Smith, K.G. and Taylor, M.S. (2007) Value Creation and Value Capture: A Multilevel Perspective. Academy of Management Review, 32, 180-194. https://doi.org/10.5465/amr.2007.23464011

[38] Kindstrom, D. (2010) Towards a Service-Based Business Model: Key Aspects for Future Competitive Advantage. European Management Journal, 28, 479-490. https://doi.org/10.1016/j.emj.2010.07.002

[39] Trott, P. (2012) Innovation Management and New Product Development. 5th Edition, Pearson Education, Essex.

[40] Kozinets, R.V., Hemetsberger, A. and Schau, H.J. (2008) The Wisdom of Consumer Crowds: Collective Innovation in the Age of Networked Marketing. Journal of Macromarketing, 28, 339-354. https://doi.org/10.1177/0276146708325382

[41] Parasuraman, A., Zeithaml, V. and Berry, L. (1985) A Conceptual Model of Service Quality and Its Implications for Future Research. Journal of Marketing, 49, 41-50. https://doi.org/10.2307/1251430 
[42] Giese, J. and Cote, J. (2000) Defining Consumer Satisfaction. Academy of Marketing Science Review, No. 1, 1-22.

[43] Sampson, S.E. and Froehle, C.M. (2006) Foundations and Implications of a Proposed Unified Service Theory. Production Operations Management Society, 15, 329-343. https://doi.org/10.1111/j.1937-5956.2006.tb00248.x

[44] Jarboe, K.P. and Furrow, R. (2008) Intangible Asset Monetization: The Promise and the Reality. Working Paper No. 3, Athena Alliance.

[45] Bosworth, B. and Collins, S. (2003) The Empirics of Growth: An Update. Brookings Institution and Georgetown University, Georgetown.

[46] Stanley Metcalfe, J. and Miles, I. (2000) Innovation Systems in the Service Economy: Measurement and Case Study Analysis. Springer, New York.

[47] Johnston, R. and Pongatichat, P. (2008) Managing the Tension between Performance Measurement and Strategy: Coping Strategies. International Journal of Operations and Production Management, 28, 941-967. https://doi.org/10.1108/01443570810903104

[48] Abreu, M., Grinevich, V., Kitson, M. and Savona, M. (2010) Policies to Enhance the Hidden Innovation in Services: Evidence and Lessons from the UK. The Service Industries Journal, 30, 99-118. https://doi.org/10.1080/02642060802236160

[49] Agrawal, K.A., Kaushikb, K.A. and Rahmanc, Z. (2015) Co-Creation of Social Value through Integration of Stakeholders. Procedia-Social and Behavioral Sciences, 189, 442-448.

[50] Von Hippel, E. (1986) Lead Users: A Source of Novel Product Concepts. Management Science, 32, 791-805. https://doi.org/10.1287/mnsc.32.7.791

[51] Vargo, S.L. and Lusch, R.F. (2008) Service-Dominant Logic: Continuing the Evolution. Journal of the Academy of marketing Science, 36, 1-10.

https://doi.org/10.1007/s11747-007-0069-6

[52] Sheth, J.N., Sisodia, R.S. and Sharma, A. (2000) The Antecedents and Consequences of Customer-Centric Marketing. Journal of the Academy of Marketing Science, 28, 55-66. https://doi.org/10.1177/0092070300281006

[53] Baron, S., Conway, T. and Warnaby, G. (2010) Relationship Marketing: A Consumer Experience Approach. Sage Publications, London.

[54] Fuat-Firat, A. and Shultz, C.J. (1997) From Segmentation to Fragmentation: Markets and Marketing Strategy in the Postmodern Era. European Journal of Marketing, 31, 183-207. https://doi.org/10.1108/EUM0000000004321

[55] Kasouf, C.J., Darroch, J., Hultman, C.M. and Miles, M.P. (2009) Service Dominant Logic: Implications at the Marketing/Entrepreneurship Interface. Journal of Research in Marketing and Entrepreneurship, 10, 57-69. https://doi.org/10.1108/01443571010996235

[56] Dahl, S. (2014) Social Media Marketing: Theories and Applications. Sage, Thousand Oaks.

[57] Vargo, S.L. and Lusch, R.F. (2004) Evolving to a New Dominant Logic for Marketing. Journal of Marketing, 68, 1-17. https://doi.org/10.1509/jmkg.68.1.1.24036

[58] McManus, J. and Botten, N. (2006) Competitive Analysis: Thinking beyond Stage One. Journal Management Services, 50, 10-15.

[59] Ardley, B., McManus, J. and Floyd, D. (2013) Does Europe Still Represent a Healthy Deal in Times of Increased Global Challenges and Reduced Levels of Growth? A Market, Service and Social Perspective of European Healthcare. Public Money \& 
Management, 33, 421-428. https://doi.org/10.1080/09540962.2013.836003

[60] Wazoku (2017). https://www.wazoku.com/

[61] Roser, T., Samson, A., Humphreys, P. and Cruz-Valdivieso, E. (2009) New Pathways to Value: Co-Creating Products by Collaborating with Customers. LSE Enterprise, London.

[62] Gustafsson, A., Kristensson, P. and Witell, L. (2012) Customer Co-Creation in Service Innovation: A Matter of Communication? Journal of Service Management, 23, 311-327. https://doi.org/10.1108/09564231211248426

[63] Mazur, J. and Piotr Zaborek, P. (2004) Validating DART Model. International Journal of Management and Economics, No. 44, 106-125.

[64] Kozinets, R.V. (2015) Netnography. John Wiley \& Sons, London.

[65] Berthon, P.R., Pitt, L.F., Plangger, K. and Shapiro, D. (2012) Marketing Meets Web 2.0, Social Media, and Creative Consumers: Implications for International Marketing Strategy. Business Horizons, 55, 261-271. https://doi.org/10.1016/j.bushor.2012.01.007

[66] Füller, J., Matzler, K. and Hoppe, M. (2008) Brand Community Members as a Source of Innovation. Journal of Product Innovation Management, 25, 608-619. https://doi.org/10.1111/j.1540-5885.2008.00325.x

[67] Pongsakornrungsilp, S. and Schroeder, J.E. (2011) Understanding Value Co-Creation in a Co-Consuming Brand Community. Marketing Theory, 11, 303-324. https://doi.org/10.1177/1470593111408178

[68] Prahalad, C.K. and Ramaswamy, V. (2004) Co-Creation Experiences: The Next Practice in Value Creation. Journal of Interactive Marketing, 18, 5-14. https://doi.org/10.1002/dir.20015

[69] Neu, W.A. and Brown, S.W. (2008) Manufacturers Forming Successful Complex Business Services: Designing an Organization to Fit the Market. International Journal of Service Industry Management, 19, 232-251. https://doi.org/10.1108/09564230810869757 